\title{
Studi Optimisasi Heat Flux dan Welding Speed pada Pengelasan Laser Fiber terhadap Lebar Lasan, Kedalaman Penetrasi dan Tegangan Sisa Esshete 1250 dengan Metode Elemen Hingga
}

\author{
Tiara Ansellya Resty Yolanda, Mas Irfan P. Hidayat, dan Wikan Jatimurti \\ Departemen Teknik Material dan Metalurgi, Fakultas Teknologi Industri, ITS, Surabaya \\ e-mail: irfan@mat-eng.its.ac.id,wikan@mat-eng.its.ac.id
}

\begin{abstract}
Abstrak-Parameter input pengelasan laser berpengaruh terhadap kualitas hasil pengelasan. Hasil pengelasan berupa lebar lasan, kedalaman penetrasi dan tegangan sisa menentukan kualitas dari sambungan logam. Penelitian ini dilakukan untuk mendapatkan hasil pengelasan laser optimal digunakan Finite Elemen Method (FEM) dan Response Surface Methodology (RSM). Proses simulasi pada material Esshete 1250 dilakukan sebanyak 12 kali dengan parameter input yang berbeda. Parameter input pertama adalah heat flux dengan variasi power input $2000 \mathrm{~W}, 2250 \mathrm{~W}, 2500 \mathrm{~W}$, dan 2750 W. Parameter input yang kedua adalah welding speed dengan variasi $2,3 \mathrm{~m} / \mathrm{min}, 3 \mathrm{~m} / \mathrm{min}$, dan $3,5 \mathrm{~m} / \mathrm{min}$. Hasil simulasi menggambarkan pengaruh heat flux yang semakin tinggi akan meningkatkan lebar lasan, memperdalam kedalaman penetrasi dan tegangan sisa. Hasil simulasi juga menggambarkan pengaruh welding speed yang semakin tinggi akan mempersempit lebar lasan, mengurangi kedalaman penetrasi, dan mengurangi tegangan sisa. Hasil dari simulasi divalidasi menggunakan persamaan matematis dan didapatkan hasil yang valid.
\end{abstract}

Kata Kunci-Esshete 1250, FEM, Laser, Pengelasan, RSM.

\section{PENDAHULUAN}

$\mathrm{P}^{\mathrm{n}}$ ENGELASAN adalah sebuah proses fabrikasi penyambungan suatu materia dengan material lainnya yang biasanya berupa logam atau material thermoplastis. Proses pengelasan dilakukan dengan mendidihkan bidang sambungan dengan menambahkan material penyambung untuk membentuk genangan material lebur yang ketika dingin akan menjadi sambungan yang kuat.

Pada beberapa tahun terakhir, metode laser welding semakin banyak dikembangkan. Laser welding adalah proses pengelasan yang dihasilkan dari konversi energi panas dari sinar laser sehingga material meleleh dan membuat sambungan dengan material yang lain. Sinar laser yang bersifat kontinu banyak digunakan untuk pengelasan yang membutuhkan kedalaman penetrasi, sedangkan pengelasan laser yang tidak kontinu banyak digunakan dalam proses pengelasan material yang tipis. Kelebihan pengelasan laser menurut Xiaodong (2010) adalah distorsi yang rendah, kecepatan pengelasan yang tinggi, dan heat affected zone (HAZ) yang sempit. Hal ini terjadi karena pengelasan menggunakan sinar laser yang monokromatik dengan daya input yang cukup, nilai iradiasi yang tinggi dan pemanasan lokal yang lebih mudah didapatkan dibandingkan dengan pengelasan konvensional selain pengelasan laser. Sementara kerugian pengelasan laser adalah pada biayanya y ang relatif mahal dan kemampuannya yang terbatas. Kedalaman penetrasi sinar laser juga bergantung pada kapasitas sistem laser. Kontroling yang cermat juga diperlukan untuk menghindari proses penguapan material di sekitar lasan karena temperatur yang tinggi.

Penelitian tentang pengelasan laser banyak dilakukan untuk mengoptimisasi parameter-parameter input proses pengelasan laser agar dihasilkan produk las an yang terbaik. Parameter yang dimaksud adalah laser power, welding speed, dan laser focal position. Respon pengelasan yang diperhatikan adalah kedalaman penetrasi, lebar lasan, struktur mikro, geometri weld pool, sifat tensile, sifat hardness, lebar HAZ, daerah fusi, dan sebagainya. Optimisasi biasanya dilakukan dengan metode elemen hingga dan dibantu oleh software-software yang mumpuni di bidangnya.

Adapun penelitian yang akan dilakukan saat ini adalah optimisasi heat flux dan welding speed pada pengelasan laser material Esshete 1250 dan membandingkan hasilnya terutama pada bagian kedalaman penetrasi dan lebar lasannya. Penelitian ini dilakukan dengan menggunakan software ANSYS 17.1 dengan metode elemen hingga yang diterapkan untuk mendapatkan hasil yang optimal.

\section{METODOLOGI}

\section{A. Metode Penelitian}

Dalam penelitian terdapat beberapa langkah kegiatan yang dilakukan untuk mencapai hasil yang diinginkan. Hal-hal yang dilakukan antara lain adalah :

Step 1 Menentukan material yang akan digunakan dan metode yang akan dilakukan. Metode yang digunakan adalah pengelas an laser fiber konduksi single pulse.

Step 2 Menentukan dimensi dan properties material Esshete 1250. Dimensi yang digunakan adalah butt joint dengan ukuran $100 \mathrm{~mm} \times 50 \mathrm{~mm} \times 3 \mathrm{~mm}$ yang dihubungkan dengan titik-titik pengelasan berdiamater 0,6 mm sebanyak 50 buah.

Step 3 Menjalankan simulasi ANSYS Workbench Trainsient Thermal untuk mendapatkan lebar las dan 
kedalaman penetrasi dan ANSYS Workbench Transient Structural untuk mendapatkan nilai tegangan sisa. Simulasi dilakukan dengan variasi parameter welding speed dan heat flux. Welding speed yang digunakan adalah 2,5 m/min, $3 \mathrm{~m} / \mathrm{min}$, dan 3,5 m/min. Heat flux yang digunakan dihitung menggunakan persamaan (1) dengan power $2000 \mathrm{~W}, 2250 \mathrm{~W}, 2500 \mathrm{~W}$ dan $2750 \mathrm{~W}$.

Step 4 Melakukan analisa hasil simulasi dan mencari nilai optimasi menggunakan Response Surface Methodology (RSM). Kriteria optimal adalah apabila lebar las minimum, kedalaman penetrasi maksimum, dan tegangan sisa minimum. Apabila belum optimal, maka kembali ke step 3 .

Step 5 Melakukan analisa data dan pembahasan. Menjelaskan apakah hasil simulasi sesuai dengan teori yang ada. Melakukan validasi untuk membuktikan kebenaran hasil simulasi.

Step 6 Menentukan kesimpulan dari penelitian.

\section{B. Spesifikasi Material dan Parameter Input Laser}

Pada simulasi ini, material yang digunakan adalah Es shete 1250 dengan spesifikasi seperti yang diuraikan pada Tabel 1 [1] dan Tabel 2 [1]. Sementara parameter yang digunakan pada pengelasan laser diuraikan pada Tabel 3 [2].

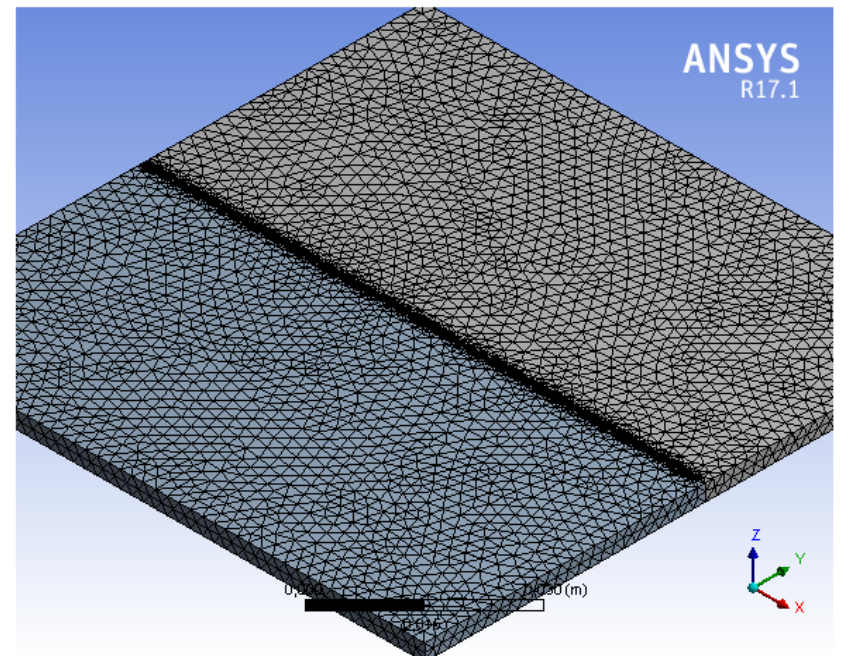

Gambar 1. Meshing pada material permodelan.

Tabel 1.

Parameter pengelasan laser

\begin{tabular}{ccc}
\hline \hline Parameter & Min & Max \\
\hline Laser power $(\mathrm{W})$ & 2000 & 2750 \\
Welding speed & 2.5 & 3.5 \\
(m/menit) & & \\
\hline \hline
\end{tabular}

Tabel 2.

Properti material Esshete 1250

\begin{tabular}{cccc}
\hline \hline $\begin{array}{c}\text { Temperatur } \\
\left({ }^{\mathbf{0}} \mathbf{C}\right)\end{array}$ & $\begin{array}{c}\text { Densit } \\
\text { as } \\
\left(\mathbf{K g} / \mathbf{m}^{\mathbf{3}}\right)\end{array}$ & $\begin{array}{c}\text { Konduktivit } \\
\text { as } \\
(\mathbf{W} / \mathbf{m} \cdot \mathbf{K})\end{array}$ & $\begin{array}{c}\text { Kalor Jenis } \\
(\mathbf{J} / \mathbf{K g} \cdot \mathbf{K})\end{array}$ \\
\hline 20 & 7960 & 12.69 & 490 \\
100 & 7930 & 13.93 & 508 \\
200 & 7890 & 15.48 & 532 \\
300 & 7850 & 17.03 & 555 \\
400 & 7810 & 18.58 & 580 \\
500 & 7770 & 20.13 & 603 \\
600 & 7730 & 21.68 & 627 \\
700 & 7680 & 23.23 & 650 \\
800 & 7640 & 24.78 & 650
\end{tabular}

\begin{tabular}{cccc}
900 & 7600 & 26.33 & 650 \\
1000 & 7550 & 27.88 & 650 \\
1100 & 7550 & 29.43 & 650 \\
1200 & 7550 & 30.98 & 650 \\
1300 & 7550 & 32.53 & 650 \\
1400 & 7550 & 34.08 & 650 \\
\hline \hline
\end{tabular}

Tabel 3.

Komposisi kimia Esshete 1250

\begin{tabular}{cc}
\hline \hline Unsur & Komposisi (\%) \\
\hline $\mathrm{C}$ & 0.1 \\
$\mathrm{Si}$ & 0.5 \\
$\mathrm{Mn}$ & 6.3 \\
$\mathrm{P}$ & $\leq 0.035$ \\
$\mathrm{~S}$ & $\leq 0.015$ \\
$\mathrm{Cr}$ & 15 \\
$\mathrm{Ni}$ & 9.5 \\
$\mathrm{Mo}$ & 1.0 \\
$\mathrm{~V}$ & 0.3 \\
$\mathrm{Nb}$ & 1.0 \\
$\mathrm{~B}$ & 0.005 \\
\hline \hline
\end{tabular}

\section{HASIL DAN PEMBAHASAN}

\section{A. Permodelan}

Simulasi dilakukan pada titik pengelasan seperti pada Gambar 2 berupa heat flux pada permukaan material. Material berada pada kondisi temperatur udara kamar $300 \mathrm{~K}$, perambatan konveksi sebesar $50 \mathrm{~W} / \mathrm{m}^{2}$, bagian bawah material diberi heat dengan tipe perfectly insulated karena bagian bawah material menempel pada meja kerja beruma magnet.

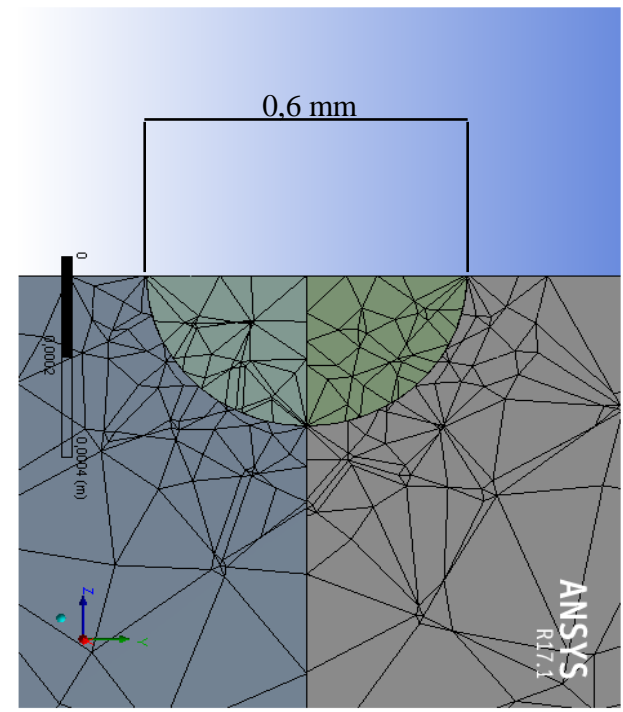

Gambar 2. Geometri weld spot

Analisa thermal akan menghasilkan output berupa lebar lasan dan kedalaman penetrasi yang dilihat dari hasil distibusi temperatur. Perhitungan lebar lasan dan kedalaman penetrasi berdasarkan temperatur fusi material Esshete 1250 sebesar $1400{ }^{\circ} \mathrm{C}$. Analisa struktural menggunakan hasil distribusi temperatur dari analis a termal dan akan dihasilkan tegangan sisa pengelasan.

\section{B. Pembebanan}

Pembebanan dilakukan dengan heat flux sesuai dengan persamaan [3]: 
$P D=\frac{P}{\left(\frac{\pi d^{2}}{4}\right)}$

Sehingga parameternya dapat dilihat pada Tabel 4. Pembebanan pada ANSYS Workbench Transient Thermal akan menghitung semua step yang aktif pada tabular data step. Oleh karena itu, load step selain pada step yang dituju haruslah dihapus dengan cara dideactive. Hal ini bertujuan agar software tidak mengkalkulasi pembebanan heat flux pada step yang dideactive tersebut. Pemberikan pembebanan heat flux dengan nilai nol tidaklah sama dengan menghapus load step tersebut. Penghapusan load step memiliki fungsi yang sama dengan deactive load step. Sementara untuk menjalankan pembebanan termal sebagai pengelasan, pengaturan yang digunakan adalah menonaktifkan auto time stepping. Step berjalan bukan dari waktu step namun dari substep yang ada. Pengaturan selanjutnya adalah dengan mengaktifkan integrasi waktu.

Tabel 4.

Parameter pengelasan pada setiap case

\begin{tabular}{|c|c|c|c|c|c|}
\hline \multirow[b]{2}{*}{ Case } & \multicolumn{2}{|c|}{ Welding Speed } & \multirow{2}{*}{$\begin{array}{c}\text { Power } \\
\text { Input } \\
(\mathrm{W})\end{array}$} & \multirow{2}{*}{$\begin{array}{l}\text { Waktu } \\
\text { (s) }\end{array}$} & \multirow{2}{*}{$\begin{array}{l}\text { Heat Flux } \\
\left(\mathrm{W} / \mathrm{m}^{2}\right)\end{array}$} \\
\hline & $(\mathrm{m} / \mathrm{min})$ & $\begin{array}{c}(\mathrm{m} / \mathrm{s} \\
)\end{array}$ & & & \\
\hline 1 & \multirow{4}{*}{2,5} & \multirow{4}{*}{$\begin{array}{c}0,04 \\
17\end{array}$} & 2000 & 2,4 & 7077140835 \\
\hline 2 & & & 2250 & 2,4 & 7961783439 \\
\hline 3 & & & 2500 & 2,4 & 8846426044 \\
\hline 4 & & & 2750 & 2,4 & 9731068648 \\
\hline 5 & \multirow{4}{*}{3} & \multirow{4}{*}{$\begin{array}{c}0,05 \\
00\end{array}$} & 2000 & 2 & 7077140835 \\
\hline 6 & & & 2250 & 2 & 7961783439 \\
\hline 7 & & & 2500 & 2 & 8846426044 \\
\hline 8 & & & 2750 & 2 & 9731068648 \\
\hline 9 & \multirow{4}{*}{3,5} & \multirow{4}{*}{$\begin{array}{c}0,05 \\
83\end{array}$} & 2000 & 1,7143 & 7077140835 \\
\hline 10 & & & 2250 & 1,7143 & 7961783439 \\
\hline 11 & & & 2500 & 1,7143 & 8846426044 \\
\hline 12 & & & 2750 & 1,7143 & 9731068648 \\
\hline
\end{tabular}

\section{Hasil Penelitian}

Hasil distribusi temperatur pda hasil pengelasan berupa rentang temperatur global maximum temperature dan global minimum temperatur seperti yang ditunjukkan pada Gambar 3 dan Gambar 4. Temperatur tertinggi pada pengelasan berada pada weld pool kemudian semakin dingin ke arah HAZ kemudian temperatur terendah beraa pada bagian base metal.



Gambar 3. Temperatur global maksimum
Perhitungan lebar lasan ditunjukkan pada Gambar 5 dan Gambar 6 dimana temperatur yang dijadikan acuan perhitungan adalah temperatur $1400^{\circ} \mathrm{C}$. Pengkuran dilakukan dengan menghitung selisih koordinat node terdekat pada temperatur tersebut.

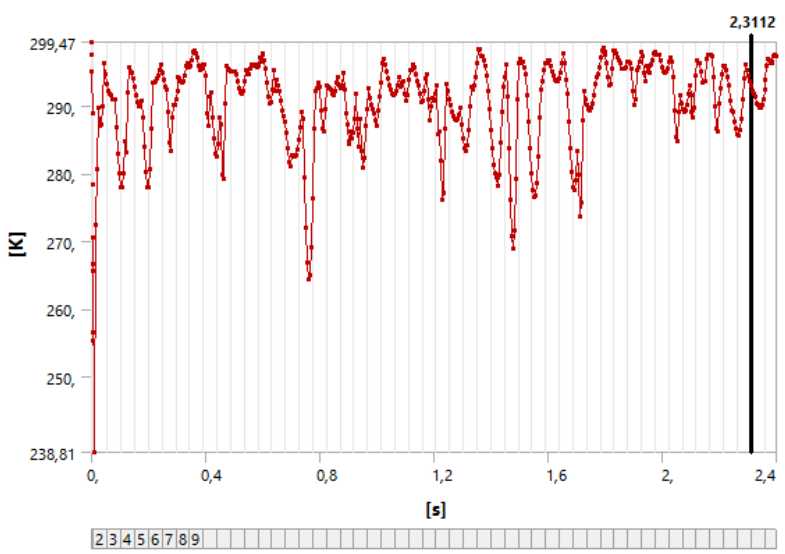

Gambar 4. Temperatur global minimum

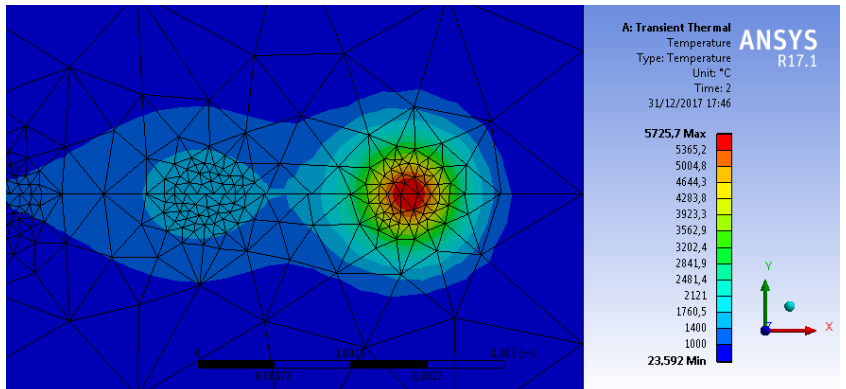

Gambar 5. Distribusi temperatur untuk menghitung lebar lasan

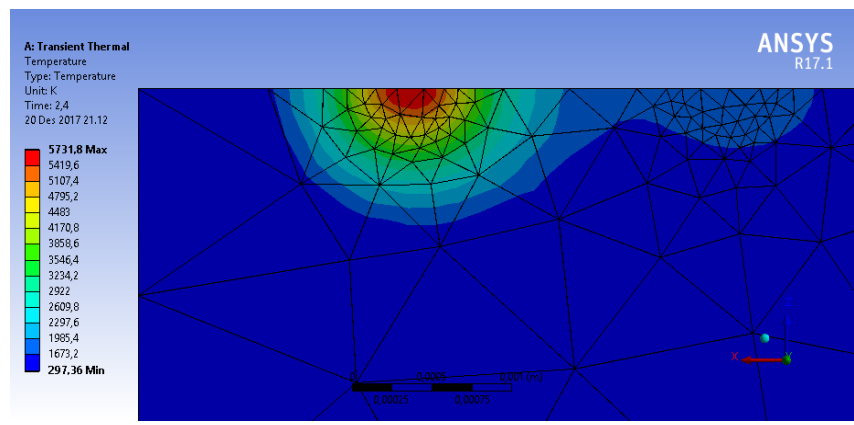

Gambar 6. Distribusi temperatur untuk menghitung kedalaman penetrasi

Tabel 5.

Ukuran bead weld dari distribusi temperatur

\begin{tabular}{ccccc}
\hline \hline Case & $\begin{array}{c}\text { Welding Speed } \\
(\mathrm{m} / \mathrm{min})\end{array}$ & $\begin{array}{c}\text { Power } \\
\text { Input } \\
(\mathrm{W})\end{array}$ & $\begin{array}{c}\text { Lebar Lasan } \\
(\mathrm{mm})\end{array}$ & $\begin{array}{c}\text { Kedalaman } \\
\text { Penetrasi } \\
(\mathrm{mm})\end{array}$ \\
\hline 1 & & 2000 & 1,7647 & 0,88 \\
2 & 2,5 & 2250 & 1,8333 & 0,8842 \\
3 & & 2500 & 1,8621 & 0,92 \\
4 & & 2750 & 1,9273 & 0,9 \\
\hline 5 & 3 & 2000 & 1,650 & 0,78 \\
6 & & 2250 & 1,644 & 0,8308 \\
7 & & 2500 & 1,680 & 0,8432 \\
8 & & 2750 & 1,740 & 0,8714 \\
\hline 9 & & 2000 & 1,6098 & 0,7692 \\
10 & 3,5 & 2250 & 1,6833 & 0,7941 \\
11 & & 2500 & 1,6769 & 0,7875 \\
12 & & 2750 & 1,695 & 0,8211 \\
\hline \hline
\end{tabular}


Dari hasil simulasi pada Tabel 5 dapat dibuat grafik seperti pada Gambar 7 dan Gambar 8. Pada Gambar 7 bahwa semakin besar power yang diterima oleh titik-titik pengelasan maka akan semakin besar lebar lasan karena distribusi temperatur yang mencapai temperatur fusi semakin besar. Pada Gambar 8 dapat dilihat dengan welding speed yang semakin besar akan menghasilkan lebar lasan yang semakin kecil, hal ini disebabkan karena waktu sinar laser untuk memanaskan titik pengelasan semakin cepat saat welding speed tinggi. Power las berpengaruh terhadap proses pelelehan dan penyambungan logam, semakin besar power maka semakin besar lebar HAZ [4]. Semakin cepat waktu yang digunakan sinar laser untuk melelehkan logam, maka panas yang ditimbulkan semakin sedikit sehingga lebar lasan semakin kecil [2].

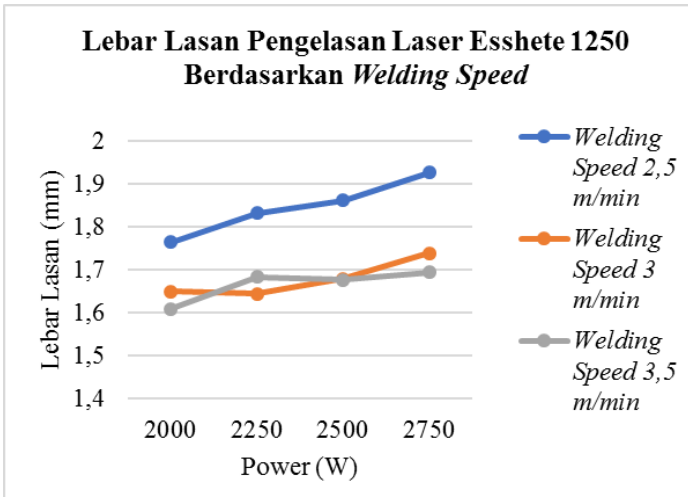

Gambar 7. Lebar lasan pengelasan laser Esshete 1250 berdasarkan welding speed

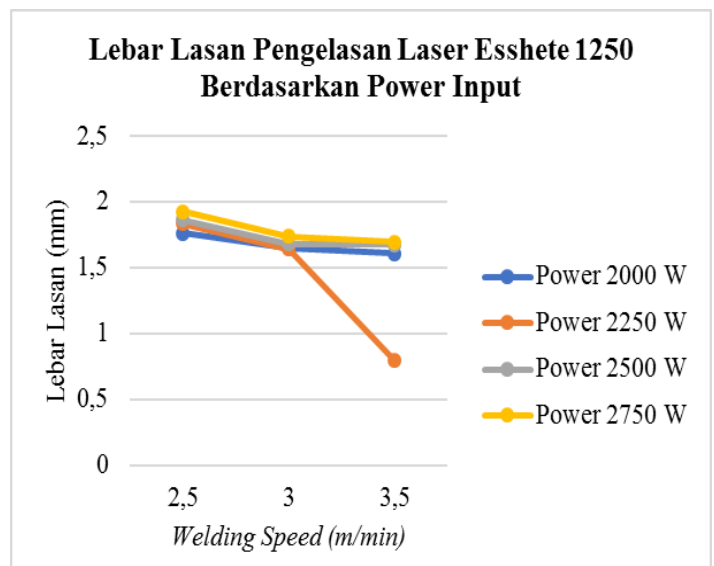

Gambar 8. Lebar lasan pengelasan laser Esshete 1250 berdasarkan power input

Kemudian pada Gambar 9 dan Gambar 10 dapat dilihat pengaruh power dan welding speed terhadap kedalaman penetrasi dan didapatkan kedalaman penetrasi yang semakin meningkat seiring dengan semakin tingginya power input. Kemudian dengan welding speed yang semakin cepat didapatkan kedalaman penetrasi yang semakin singkat. Semakin tinggi arus pengelasan maka akan semakin memperdalam penetrasi [5][6]. Semakin besar kecepatan pengelasan maka akan menghasilkan waktu pelelehan yang semakin cepat sehingga material yang meleleh semakin sedikit akibatnya kedalaman penetrasi akan berkurang [5].

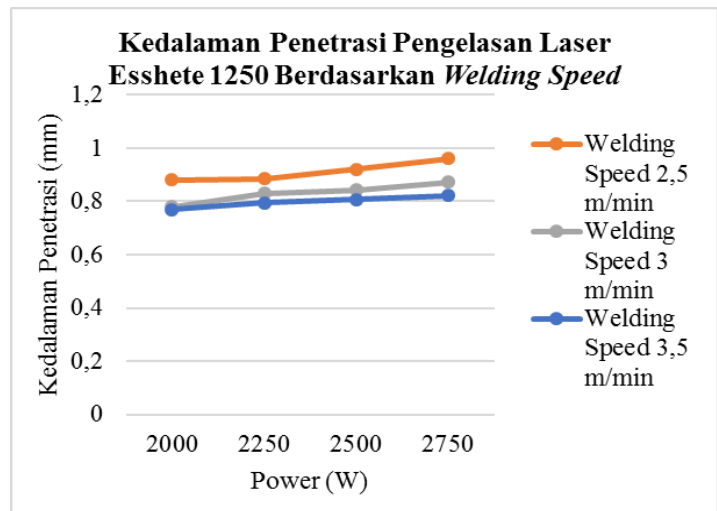

Gambar 9. Kedalaman penet rasi pengelasan laser Esshete 1250 berdasarkan welding speed



Gambar 10. Kedalaman penetrasi pengelasan laser Esshete 1250 berdasarkan power input

Tabel 6 merupakan hasil simulasi tegangan sisa pada 12 simulasi. Dari Tabel 6 dapat digambarkan hasil pengaruh power input dan welding speed seperti pada Gambar 11 dan Gambar 12. Pada Gambar 11 dapat dilihat semakin tinggi power input didapatkan tegangan sisa yang semakin besar. Hal ini terjadi karena distribusi temperatur yang dihasilkan pada power input yang tinggi akan semakin besar. Kemudian Gambar 12 dengan semakin besarnya welding speed maka waktu yang dibutuhkan setiap titik semakin cepat. Sehingga tegangan sisa dari hasil distribusi temperatur juga semakin kecil. Hasil simulasi tegangan sisa ini sesuai dengan penelitian yang dilakukan pada Jurnal [7].

Tabel 6.

Hasil pengukuran tegangan sisa pada pengelasan

\begin{tabular}{cccc}
\hline \hline Case & $\begin{array}{c}\text { Welding Speed } \\
(\mathrm{m} / \mathrm{min})\end{array}$ & $\begin{array}{c}\text { Power Input } \\
(\mathrm{W})\end{array}$ & $\begin{array}{c}\text { Tegangan } \\
\text { Sisa }(\mathrm{Pa})\end{array}$ \\
\hline 1 & & 2000 & 0,20444 \\
2 & \multirow{2}{*}{2,5} & 2250 & 0,20486 \\
3 & & 2500 & 0,20532 \\
4 & & 2750 & 0,20584 \\
\hline 5 & & 2000 & 0,20393 \\
6 & 3 & 2250 & 0,20429 \\
7 & & 2500 & 0,20476 \\
8 & & 2750 & 0,20529 \\
\hline 9 & & 2000 & 0,19931 \\
10 & 3,5 & 2250 & 0,19975 \\
11 & & 2500 & 0,20023 \\
12 & & 2750 & 0,20077 \\
\hline \hline
\end{tabular}




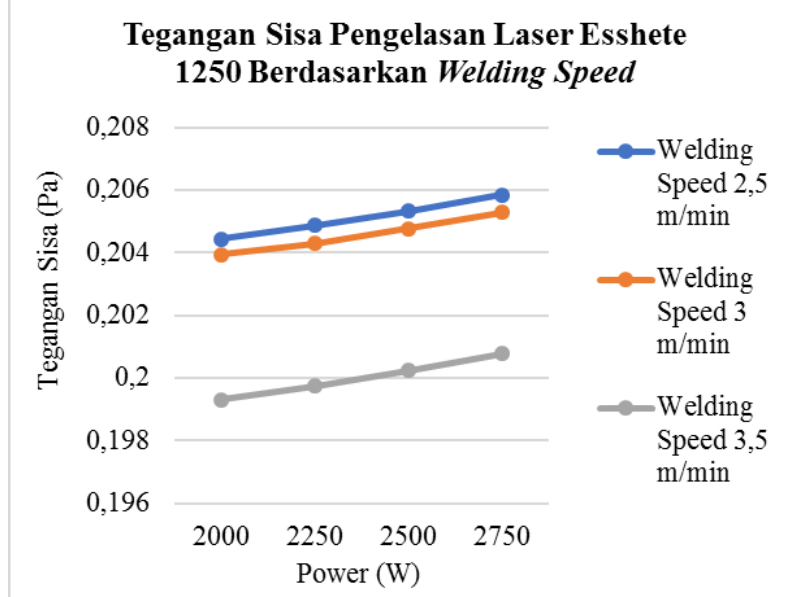

Gambar 11. Tegangan sisa pengelasan laser Esshete 1250 berdasarkan welding speed

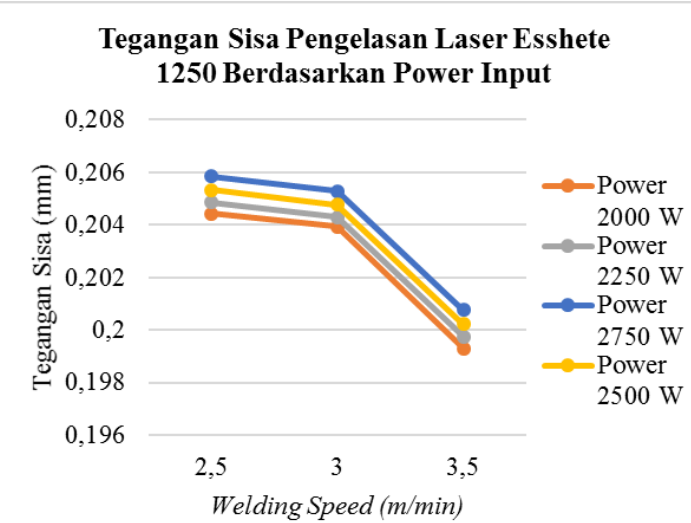

Gambar 12. Tegangan sisa pengelasan laser Esshete 1250 berdasarkan power input

\section{Optimasi Hasil Simulasi}

Desain eksperimen untuk menganalisa pengaruh power input dan welding speed ditunjukkan pada Tabel 7. Tabel ini mendistribusikan angka Std Order, Run Order, dan Blocks sesuai dengan analis a data Response Surface Methodology. Second-order polynomial (regresi) [7] dijelaskan dalam bentuk Y.

$$
Y=A+a_{1} X_{1}+a_{2} X_{2}+a_{2} X_{1}^{2}+a_{4} X_{2}^{2}+a_{5} X_{1} X_{2}
$$

dimana A menjelaskan rata-rata aritmatika dari semua hasil kuantitatif yang dihasilkan 12 simulasi, a 1 sampai as adalah koefisien, dan $X_{1}, X_{2}$ merupakan parameter input yang dijadikan variabel kontrol.

Tabel 7

Desain eksperimen dan analisis RSM

\begin{tabular}{cccccccc}
\hline \hline $\begin{array}{c}\text { Std } \\
\text { Orde } \\
\mathrm{r}\end{array}$ & $\begin{array}{c}\text { Run } \\
\text { Orde } \\
\mathrm{r}\end{array}$ & $\begin{array}{c}\text { Block } \\
\mathrm{s}\end{array}$ & $\begin{array}{c}\mathrm{WS} \\
(\mathrm{m} / \mathrm{min}\end{array}$ & $\begin{array}{c}\mathrm{P} \\
(\mathrm{W})\end{array}$ & $\begin{array}{c}\mathrm{LL} \\
(\mathrm{mm})\end{array}$ & $\begin{array}{c}\mathrm{KP} \\
(\mathrm{mm})\end{array}$ & $\begin{array}{c}\mathrm{TS} \\
(\mathrm{Pa})\end{array}$ \\
\hline 1 & 1 & 1 & 2,5 & $\begin{array}{c}200 \\
0\end{array}$ & $\begin{array}{c}1,764 \\
7\end{array}$ & 0,88 & $\begin{array}{c}0,2044 \\
4\end{array}$ \\
& & & & 225 & 1,833 & 0,884 & 0,2048 \\
2 & 2 & 1 & 2,5 & 0 & 3 & 2 & 6 \\
& & & & 250 & 1,862 & & 0,2053 \\
3 & 3 & 1 & 2,5 & 0 & 1 & 0,92 & 2 \\
4 & 4 & 1 & 2,5 & 275 & 1,927 & & 0,2058 \\
& & & & 0 & 3 & 0,9 & 4 \\
5 & 5 & 1 & 3 & 200 & & & 0,2039 \\
6 & 6 & 1 & 3 & 225 & 1,733 & 0,78 & 3 \\
& & & & & & & 0,2043
\end{tabular}

\begin{tabular}{|c|c|c|c|c|c|c|c|}
\hline \multirow{3}{*}{7} & \multirow{3}{*}{7} & & & 0 & 3 & 8 & 9 \\
\hline & & \multirow{2}{*}{1} & \multirow{2}{*}{3} & 250 & 1,714 & 0,843 & 0,2047 \\
\hline & & & & 0 & 3 & 2 & 6 \\
\hline \multirow{2}{*}{8} & \multirow{2}{*}{8} & \multirow{2}{*}{1} & \multirow{2}{*}{3} & 275 & & 0,871 & 0,2052 \\
\hline & & & & 0 & 1,74 & 4 & 9 \\
\hline \multirow{2}{*}{9} & \multirow{2}{*}{9} & \multirow{2}{*}{1} & \multirow{2}{*}{3,5} & 200 & 1,609 & 0,769 & 0,1993 \\
\hline & & & & 0 & 8 & 2 & 1 \\
\hline \multirow{2}{*}{10} & \multirow{2}{*}{10} & \multirow{2}{*}{1} & \multirow{2}{*}{3,5} & 225 & 1,683 & 0,794 & 0,1997 \\
\hline & & & & 0 & 3 & 1 & 5 \\
\hline \multirow{2}{*}{11} & \multirow{2}{*}{11} & \multirow{2}{*}{1} & \multirow{2}{*}{3,5} & 250 & 1,676 & 0,787 & 0,2002 \\
\hline & & & & 0 & 9 & 5 & 3 \\
\hline \multirow{2}{*}{12} & \multirow{2}{*}{12} & \multirow{2}{*}{1} & \multirow{2}{*}{3,5} & 275 & & 0,821 & 0,2007 \\
\hline & & & & 0 & 1,695 & 1 & 7 \\
\hline
\end{tabular}

Surface Plot of Lebar Lasan (mm) vs Power (W); Welding Speed ( $\mathrm{m} / \mathrm{min}$ )

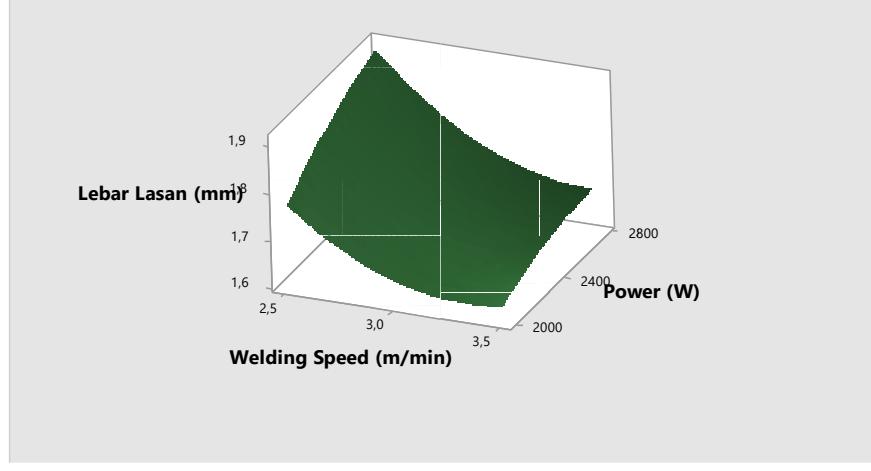

Gambar 13. Surface plot simulasi lebar lasan

Surface Plot of Kedalaman Penetrasi (mm) vs Power (W); Welding Speed (

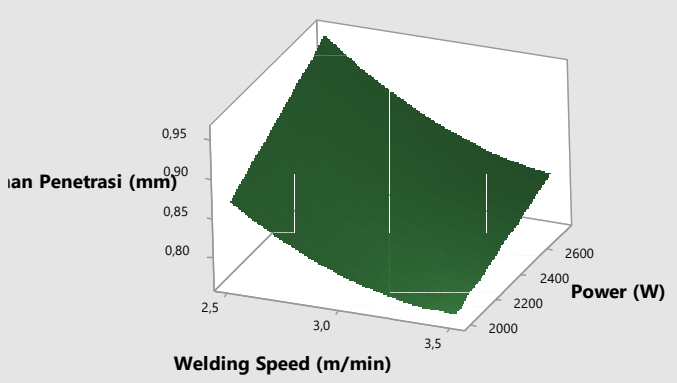

Gambar 14. Surface plot simulasi kedalaman penetrasi

Surface Plot of Tegangan Sisa (Pa) vs Power (W); Welding Speed ( $\mathrm{m} / \mathrm{min}$ )

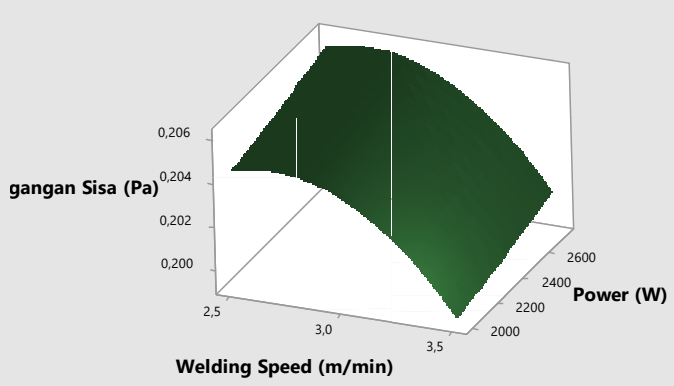

Gambar 15. Surface plot simulasi tegangan sisa

Dari hasil analisa RSM pada lebar lasan, kedalaman penetrasi dan tegangan sisa didapatkan nilai optimasi seperti pada Gambar 16. Lebar lasan yang minimum, kedalaman 
penetrasi maksimum, dan tegangan sisa minimum akan didapatkan pada welding speed sebesar $2,5 \mathrm{~m} / \mathrm{min}$ dan dengan power $2000 \mathrm{~W}$.

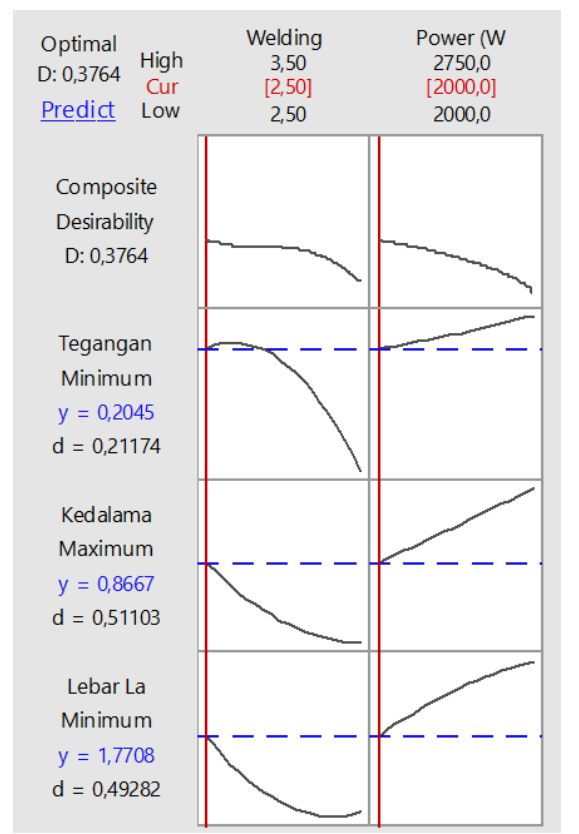

Gambar 16. Optimasi respon pengelasan laser Esshete 1250

\section{Validasi Hasil Simulasi}

Validasi hasil simulasi dilakukan dengan menghitung lebar lasan, kedalaman penetrasi, dan tegangan sisa menggunakan rumus matematik untuk membuktikan bahwa hasil simulasi benar. Validasi pada lebar lasan dilakukan dengan menggunakan persamaan berikut [3] :

$$
\frac{1}{T_{p}-T_{0}}=\frac{\sqrt{2 \pi e} \rho \operatorname{ChY} Y_{z}}{H_{\text {net }}}+\frac{1}{T_{m}-T_{0}}
$$

dimana $T_{p}$ peak temperature, $T_{0}$ temperatur awal, $\pi$ bernilai 3,1416, e bernilai 2,718, $\rho$ densitas logam induk, $C$ spesific heat, $h$ ketebalanan benda kerja, $Y_{z}$ jarak HAZ dari pusat weld pool, $\mathrm{H}_{\text {nett }}$ net heat input per satuan panjang, dan $T_{m}$ temperatur leleh. Validasi yang dilakukan pada kedalaman penetrasi adalah dengan menggunakan persamaan berikut [8] :

$$
h=\frac{P}{\rho D v\left[c\left(T_{m}-T_{0}\right)+L_{m}\right]}
$$

dimana $P$ power for melting, $\rho$ densitas logam induk, $D$ diameter laser, $h$ kedalaman penetrasi, $v$ welding speed, dan $L_{m}$ latent heat of melting.

Tabel 8 .

Hasil validasi matemat is

\begin{tabular}{lccc}
\hline \multicolumn{1}{c}{ Parameter } & Simulasi & $\begin{array}{c}\text { Perhitunga } \\
\mathrm{n}\end{array}$ & Eror \\
\hline $\begin{array}{l}\text { Temperatur Lebar } \\
\text { Lasan }\end{array}$ & $1000 \mathrm{~K}$ & $990,52 \mathrm{~K}$ & $0,948 \%$ \\
Kedalaman Penetrasi & $\begin{array}{c}0,88 \\
\mathrm{~mm}\end{array}$ & 0,89042 & $1,184 \%$ \\
\hline \hline
\end{tabular}

\section{KESIMPULAN}

1. Heat flux yang semakin tinggi dapat meningkatkan lebar lasan, meningkatkan kedalaman penetrasi, dan meningkatkan tegangan sisa
2. Welding speed yang semakin tinggi dapat mengurangi lebar lasan, mengurangi kedalaman penetrasi dan mengurangi tegangan sisa

3. Hasil pengelasan yang optimal akan didapatkan pada power sebesar $2000 \mathrm{~W}$ yang menghasilkan heat flux $7077140835 \mathrm{~W} / \mathrm{m}^{2}$ dan welding speed $2,5 \mathrm{~m} / \mathrm{min}$ dengan eror $0,948 \%$ pada lebar lasan dan 1,184\% pada kedalaman penetrasi jika dibandingkan dengan nilai validasi.

\section{DAFTAR PUSTAKA}

[1] Sandvik, "Esshete 1250: Tube and Pipe," 2017.

[2] L. S. \& X. L. Jiang P., Chaochao W., Qi Z., Xinyu S., "Optimization of Laser Welding Process Parameters of Stainless Steel 316L Using FEM, Kriging and NSGA-II," 2016.

[3] C. L. J. dan A. O'Brien, AWS Handbook Vol 1: Welding Science and Technology. 2001.

[4] dan D. K. Mutiara E., Tri Y., Dedi H., "Pengaruh Parameter Proses Pengelasan Terhadap Karakteristik Hasil Las dengan Resistance Welding Machine," 1998.

[5] R. Dani, "Pengaruh Variasi Kecepatan Pengelasan Tungsten Inert Gas (TIG) terhadap Kekuatan Tarik Hasil Sambungan Las pada Baja Karbon Rendah (ST 41)."

[6] S. H. D. R. S, Pengantar untuk Memahami Proses Pengelasan Logam. Bandung: Alabeta, 2006.

[7] R. S. \& M. V. Ragavendran M., N. Chandrasekhar, R. Ravikumar., "Optimization of Hybrid Laser - TIG Welding of 316LN Steel Using Response Surface Methodology (RSM)," 2017.

[8] X. Xue, "Effect of Pulsed Nd:YAG Laser Welding Parameters on Penetration and Microstructure Characterization of a DP 1000 Steel Butt Joint," 2017. 